\title{
Masyarakat dan Solidaritas dalam Pembangunan yang Berpotensi Konfllik (Pengabdian Masyarakat Berbasis Riset di Kecamatan Lembang Jaya Kabupaten Solok)
}

\author{
Arief Irvan \\ Universitas Andalas, Indonesia \\ E-mail:indeskaputra@gmail.com
}

\begin{abstract}
2021 by the authors. Submitted for possible open access publication under the terms and conditions of the Creative Commons Attribution-ShareAlike 4.0 International License-(CC-BY-SA) (https://creativecommons.org/licenses/by-sa/4.0/)

di) DOI: $h$ ttp://dx.doi.org $/ 10.30983 /$ dedikasia.vlil.5023
\end{abstract}

\begin{tabular}{|c|c|}
\hline ARTICLE INFO & ABSTRACT \\
\hline $\begin{array}{l}\text { Submit : 09 Februari } 2021 \\
\text { Revised : } 24 \text { Mei } 2021 \\
\text { Accepted : } 30 \text { Juni } 2021 \\
\\
\text { Keywords: } \\
\text { Kepentingan; Konflik; Solidaritas; } \\
\text { Perlawanan. }\end{array}$ & $\begin{array}{l}\text { Pengabdian masyarakat berbasis riset ini bertujuan untuk memberikan } \\
\text { pemahaman kepada masyarakat akan pentingnya pembangunan disatu sisi } \\
\text { dan pentingnya pelestarian lingkungan disisi lain. Pengabdian masyarakat } \\
\text { ini didasarkan pada riset awal yang dilakukan di nagari Bukit Sileh dan } \\
\text { nagari Batu Bajanjang di kecamatan Lembang Jaya Kabupaten Solok. } \\
\text { dengan adanya kasus munculnya solidaritas dan perlawanan masyarakat } \\
\text { terhadap pembangunan PLTP Geothermal. Pengabdian masyarakat ini } \\
\text { dengan jenis penelitian berbasis riset dengan metode Participatory Action } \\
\text { Research (PAR), dengan melibatkan partisipsi dalam diskusi maupun } \\
\text { menggali akar masalah. Riset awal sebagai dasar pengabdian dapat } \\
\text { dipahami bahwa timbulnya solidaritas masyarakat dalam penolakan } \\
\text { sebagian masyarakat terhadap pembangunan PLTP Geothermal. } \\
\text { Berdasarkan kajian riset awal di atas maka pengabdian yang dilakukan } \\
\text { dalam dua tema khusus berupa penyuluhan pentingnya pemahaman akan } \\
\text { pembangunan dan dampak positif dan negatifnya bagi kesejahteraan } \\
\text { masyaraka serta pemahaman masyarakat akan pentingnya menjaga } \\
\text { lingkungan dan dampaknya bagi masyarakat sehingga masyarakat dapat } \\
\text { memahami dan menilai akan pembangunan dari dua sisi berupa dampak } \\
\text { negatif dan positifnya bagi masyarakat sebagai efekyang ditimbulkan dari } \\
\text { pembangunan }\end{array}$ \\
\hline $\begin{array}{l}\text { International License-(CC-BY-SA) } \\
\text { (https://creativecommons.org/licenses/by-sa/4.0/) } \\
\text { do) } h t t p: / / d x . d o i . o r g / 10.30983 / \text { dedikasia.vli1.5023 }\end{array}$ & This is an open access article under the CC-BY-SA license \\
\hline
\end{tabular}

\section{Pendahuluan}

Konflik merupakan hal yang paling sering terjadi dalam kehidupan sehari-hari maupun dalam kehidupan bermasyarakat karena konflik merupakan sesuatu hal yang pasti dan akan selalu terjadi karena konflik bersifat inheren atau berdampingan dengan masyarakat itu sendiri. Konflik terjadi karena adanya kepentingan dan tujuan yang berbeda dari dua pihak atau lebih dengan tujuan yang sama untuk menguasai sumber daya yang diperebutkan. Konflik dapat terjadi antara pemerintah dengan masyarakat, 
maupun masyarakat dengan pihak swasta. Namun, ada pula konflik kepentingan yang melibatkan pemerintah, masyarakat dan swasta secara bersamaan.

Istilah konflik secar etimologi berasal dari bahasa latin con yang memilki arti bersama dan figure memiliki arti benturan atau tabrakan (Elly \& Usman, 2011). Para ahli sosiologi juga menjelaskan pengertian dari konflik, Menurut Cosser konflik sosial adalah perjuangan terhadap nilai dan pengakuan terhadap status yang langka, selanjutnya kekuasaan dan sumber - sumber pertentangan dinetralisir atau dilangsungkan atau dieleminir saingannya (Irving, 1998). Soerjano Sukanto juga mengartikan konflik suatu proses sosial yang melibatkan individu atau kelompok yang saling menentang dan ancaman kekerasan(Soekanto, 1993). secara sosiologis konflik diartikan harus melibatkan dua pihak atau lebih dan konflik itu berkaitan dengan persepsi, ada satu pihak yang mempersepsikan kepentingan dia berbeda dengan pihak yang lain.

Salah satu konflik yang terjadi di Provinsi Sumatera Barat adalah konflik yang melibatkan masyarakat didua nagari, yaitu Nagari Batu Bajanjang dan Nagari Bukit Sileh, Kecamatan Lembang Jaya, Kabupaten Solok dengan pihak PT Hitay Daya Energy dalam pembangunan pembangkit listrik tenaga panas bumi (PLTP) geothermal. Konflik ini bermula Pada tahun 2016 keseriusan pemerintah kabupaten solok dan provinsi Sumatera Barat bersama kementerian ESDM mengeluarkan surat izin dan memberikan wewenang kepada PT Hitay Daya Energy untuk melakukan eksplorasi potensi panas bumi serta dikembangan untuk menjadi pembangkit listrik tenaga panas bumi geothermal Gunung Talang. Pada tahun 2017 pengerjaan tersebut mengalami kendala karena adanya resistensi (perlawanan) dilakukan oleh masyarakat di dua Nagari yaitu Nagari Batu Bajanjang dan Nagari Bukik Sileh untuk menolak pembangunan PLTP Gunung Talang (Sari, 2020).

Alasan penolakan masayarakat adalah : (1) penjajakan lahan yang dilakukan oleh utusan PT Hitay Daya Energy secara diam - diam yang masuk ke wilayah pertanian yang dimiliki masyarakat, (2) proses sosialiasai yang dilakukan oleh pemerintah dan juga PT Hitay Daya Energy tidak berjalan dengan baik cendrung arogan, (3) Tanah ulayat yang dimilki oleh kaum diberikan oleh ninik mamak kepada PT Hitay Daya Energy tanpa sepengetahun masyarakat kaum / kemanakan., (3) pembangunan PLTP geothermal Gunung Talang dikawatirkan masyarakat akan menimbulkan bencana alam seperti longsor, kekeringan, polusi udara, kehilangan mata pencarian dan ketakutan masyarakat seperti kejadian lumpur lapindo di Siduarjo. Selain itu perlawanan dari masyarakat juga disebabkan dari tiga alasan, tiga alasan tersebut adalah pertama faktor pengetahuan, kedua faktor ekonomi, faktor sosial budaya (Eril, 2019).

Adanya wacana pembebasan lahan sebanyak 27.00 Ha untuk pembangunan PLTP Geotermal gunung Talang membuat masyarakat melakukan penolakan dan perlawanan terhadap kegiatan eksplorasi tersebut. Hal itu dikarenakan ketakutan masyarakat kehilangan mata pencaharaian dan tempat tinggal. Di sisi lain, pemerintah bersama PT Hitay Daya Energy berusaha keras untuk melakukan kegiatan 
eksplorasi untuk pembangunan PLTP Geotermal gunung Talang dengan melibatkan pemerintah daerah sampai ke pemerintahan terendah yaitu pemerintah serta nagari aparat keamanan untuk melakukan tindakan represif (menekan) masyarakat. Akan tetapi masyarakat tidak merasa takut dan dan tetap melakukan penolakan serta perlawanan kepada pemerintah dan pihak PT Hitay Daya Energy. Ketidakberpihakan pemerintah baik di tingkat kabupaten, kecamatan maupun nagari kepada masyarakat pada akhirnya menimbulkan perlawanan serta penolakan yang berujung demonstrasi besarbesaran beberapa kali yang ditujukan oleh masyarakat selingkaran kaki gunung Talang kepada pemerintah serta PT. Hitay Daya Energi. Demontrasi yang dilakukan oleh masyarakat nagari salingka gunung Talang dilakukan sebayak dua kali. Aksi pertama dilakukan pada bulan September tahun 2017 di kantor Bupati Kabupaten Solok dan berlangsung secara aman. Kemudian aksi demontrasi kedua dilakukan pada bulan Oktober tahun 2017 yang melibatkan lebih banyak massa dari masyarakat salingka gunung Talang dan berlangsung ricuh karena Bupati Kabupaten Solok tidak menemui massa (Juli, 2021).

Setelah masyarakat melakukan aksi sebanyak dua kali, akan tetapi pihak PT. Hitay Daya Energy serta pihak pemerintah tetap datang ke lokasi dan akan tetap melakukan rencana eksplorasi LPTP Geotermal tanpa mengindahkan aspirasi masyarakat. Masyarakat tetap melakukan penolakan yang mengakibatkan terjadinya kericuhan serta pembakaran satu unit mobil milik PT. Hitay Daya Energy oleh masyarakat. Dari pembakaran satu unit mobil tersebut berujung kepada penangkapan beberapa orang masyarakat yang melakukan demontrasi. Setelah penangkapan tersebut aksi penolakan dari masyarakat masih terus terjadi dan masih terjadi kericuhan dengan pihak-pihak yang memiliki kepentingan.

Setelah terjadinya konflik tersebut masyarakat nagari batu bajanjang dan bukik sileh terbagi menjadi menjadi dua yaitu masyarakat yang pro dan kontra terhadap pembangunan PLTP Geotermal Gunung Talang. Dan masyarakat kehilangan kepercayaan kepada niniak mamak, pemerintah nagari, pemerintah daerah, pemerintah provinsi serta aparat keamanan. Selain itu masyarakat juga sangat waspada dan penuh curiga kepada orang asing yang masuk ke dalam nagari mereka karena dianggap sebagai matamata pihak perusahaan.

Sebelumnya kehidupan masyarakat di nagari Batu Bajanjang dan Bukik Sileh sangat aman dan damai. Masyarakat hidup dengan semangat gotong royong dan saling menghormati satu sama lain. Mayoritas mata pencaharian masyarakat di nagari Batu Bajanjang dan Bukik Sileh adalah bercocok tanam (sayursayuran). Serta kepercayaan masyarakat kepada lembaga adat terutama kepada ninik mamak masih kuat. Tidak salah juga kepercayaan masayarakat kepada pihak pemerintah nagarai serta daerah harmonis dan aparat yang ada di nagari tetap dipercaya oleh masayrakat. Akan tetapi semenjak adanya rencana pembangunan PLTP geothermal Gunung Talanng oleh pemerintah serta pihak swasta PT Hitay Daya Energy mengakibatkan penolakan berujung kepada demonstarsi, kericuhan bahkan kekerasan yang berdampak kehilangan kepercayaan masyarakat serta perubhan sosial pada masyarakat. 
Sehubungan dengan hal terjadinya potensi konflik, maka dipandang perlu memberikan pemahaman kepada masyakarakat melalui penyuluhan berbasis riset dalam menganalisis tentang bagaimana solidaritas yang dibangun oleh masyarakat untuk melawan pembangunan yang berpotensi konflik dalam kehidupan sosial masyarakat tersebut dan memberikan pemahaman kepada masyarakat akan pembenabgunan.

\section{Metode}

Metode yang digunakan dalam kegiatan pengabdian masyarakat ini, dengan metode Pengabdian berbasis riset dengan melakukan penelitian awal sebagai dasar dalam melaksanakan penyuluhan bagi masyarakat. Penyuluhan ini dilakukan di Nagari Bukik Sileh dan Nagari Batu Bajanjang Kecamatan Lembang Jaya Kabupaten Solok. Penyuluhan ini berkaitan dengan pemahaman masyarakat tentang pembangunan dan juga lingkungan karena adanya pembangunan PLTP Geothermal Gunung Talang.

\section{Hasil}

Pengabdian masyarakat ini merupakan pengabdian berbasis riset dengan melaksanakan suatu kajian dan riset terlebih dahulu sebelum kegiatan pengabdian masyarakat dilakukan. Kajian riset sebelum sebelum pengabdian ini mengkaji dan menganalisis kasus di tengah-tengah masyarakat untuk melihat bentuk solidaritas masyarakat Nagari Bukik Sileh dan Nagari Batu Bajanjang penulis menggunakan teori konflik dari Lewis A. Coser. Bagi Coser konflik merupakan proses yang bersifat instrumental dalam pembentukan, penyatuan dan pemiliharaan struktur sosial. Konflik dapat menempatkan dan menjaga garis batas antara dua atau lebih kelompok. Konflik dengan kelompok lain dapat memperkuat kembali identitas kelompok dan melindungi agar tidak lebur ke dalam dunia sosial sekelilingnya (Wahid, 2017). Coser memiliki pandangan bahwa konflik dalam masyarakat merupakan peristiwa normal yang dapat memperkuat struktur hubungan-hubungan sosial. Tidak adanya konflik dalam suatu masyarakat tidak dapat dianggap sebagai petunjuk kekuatan dan stabilitas hubungan sosial masyarakat. Perkembangan konflik dalam masyarakat bukanlah merupakan indikator utama dan tunggal untuk mengatakan bahwa stabilitas sosial dari masyarakat itu telah tercapai (Khusniati, 2016).

Seluruh fungsi positif konflik tersebut dapat dilihat dalam ilustrasi suatu kelompok yang sedang mengalami konflik dengan kelompok lain. Coser melihat katup penyelamat berfungsi sebagai jalan keluar yang meredakan permusuhan, yang tanpa itu hubungan-hubungan diantara pihak-pihak yang bertentangan akan semakin menajam. Katup penyelamat (Savety-Valve) ialah salah satu mekanisme khusus yang dapat dipakai untuk mempertahankan kelompok dari kemungkinan konflik sosial. Katup penyelamat merupakan sebuah institusi pengungkapan rasa tidak puas atas sebuah sistem atau struktur. 
Menurut Coser konflik dibagi menjadi dua macam, yaitu: konflik realistis, berasal dari kekecewaan terhadap tuntutan-tuntutan khusus yang terjadi di dalam hubungan dan dari perkiraan kemungkinan keuntungan para partisipan, dan yang ditujukan pada obyek yang dianggap mengecewakan. Konflik non-realistis, konflik yang bukan berasal dari tujuan-tujuan saingan yang antagonis, tetapi dari kebutuhan untuk meredakan ketegangan, paling tidak dari salah satu pihak. Akan tetapi apabila konflik berkembang di dalam hubungan-hubungan yang intim, maka pemisahan (antara konflik realistis dan non-realistis) akan lebih sulit untuk dipertahankan. Coser menyatakan bahwa semakin dekat suatu hubungan maka semakin besar rasa kasih sayang yang sudah tertanam, sehingga semakin besar juga kecenderungan untuk menekan ketimbang mengungkapkan rasa permusuhan. Hal ini tidak selalu bisa terjadi dalam hubungan-hubungan primer dimana keterlibatan total para partisipan membuat pengungkapan perasaan yang demikian merupakan bahaya bagi hubungan tersebut. Apabila konflik tersebut benar-benar melampaui batas sehingga menyebabkan ledakan yang membahayakan hubungan tersebut.

Coser mengutup hasil pengamatan Simmel yang meredakan ketegangan yang terjadi dalam suatu kelompok. Dia menjelaskan bukti yang berasal dari hasil pengamatan terhadap masyarakat Yahudi bahwa peningkatan konflik kelompok dapat dihubungkan dengan peningkatan interaksi dengan masyarakat secara keseluruhan. Bila konflik dalam kelompok tidak ada, berarti menunjukan lemahnya integrasi kelompok tersebut dengan masyarakat. Dalam struktur besar atau kecil konflik in-grup merupakan indikator adanya suatu hubungan yang sehat. Coser sangat menentang para ahli sosiologi yang selalu melihat konflik hanya dalam pandangan negatif saja. Perbedaan merupakan peristiwa normal yang sebenarnya dapat memperkuat struktur sosial. Dengan demikian Coser menolak bahwa ketiadaan konflik sebagai indikator dari kekuatan dan kestabilan suatu hubungan.

Pengabdian masyarakat berbasis riset ini diawali dengan penelitian awal sebagai dasar dalam pengabdian masyarakat untuk mengetahui karakteristik demografi, ekonomi, pendidikan, sumber daya, persepsi masyarakat Batu Bajanjang tentang rencana pembangunan PLTP Gunung Talang - Bikit Kili Kabupaten Solok. Hasil dari penelitian awal sebagai dasar berpijak dari pengabdian masyarakat berbasis riset ini adalah karakteristik demografi jenis kelamin perempuan adalah (55\%), kategori usia produktif (87\%), pribumi (71\%), lama tinggal > 10 tahun (85\%). Tingkat pendidikan menengah ke bawah (42\% SLTA). Sumber informasi dari media sosial adalah (46\%). Penghasilan diatas Rp. 3.000.000 (56\%), pekerjaan petani (37\%), kepemilikian tanah di area PLTP (19\%). Persepsi dengan indicator setuju adalah (40\%), tidak setuju (36\%), netral (24\%). Indicator persepsi aspek ekonomi tanggapan netral (54,59\%), aspek sosial netral (60,94\%), aspek lingkungan netral (43,08\%). Kategori responden secara keseluruahn netral adalah $(56,08 \%)$. 
Kegiatan pengabdian masyarakat berbasis riset yang dilakukan untuk menganalisis dan mengkaji solidaritas masyarakat Nagari Bukik Sileh dan Nagari Batu Bajanjang Kecamatan Lembang Jaya Kabaupaten Solok dalam usaha penolakan pembangunan PLTP geothermal Gunung Talang dan melakukan penyuluhan akan pembangunan dan lingkungan hidup. Riset awal yang dilakukan di Nagari Bukik Sileh dan Nagari Batu Bajanjang Kecamatan Lembang Jaya Kabupaten Solok dalam usaha penolakan pembangunan PLTP Geothermal Gunung Talang adalah sebagai berikut:

1. Membentuk HIMAPAGTA (Himpunan Masyarakat Pencinta Gunung Talang)

Salah satu bentuk solidaritas yang dilakukan oleh masyarakat Nagari Bukik Sileh dan Batu Bajanjang dengan membentuk Himpunan Masyarakat Pencinta Gunung Talang (HIMAPAGTA). Solidaritas yang dilakukan oleh masyarakat yang tergabung dalam komunitas HIMAPAGTA karena merasa khawatir dengan adanya wacana pembangunan Gheotermal yang akan memiliki dampak terhadap kerusakan lingkungan dan mata pencaharian masyarakat. Bagi masyarakat Nagari Bukik Sileh dan Batu Bajanjang yang bekerja sebagai petani selama ini memanfaatkan alam untuk mencari kehidupan. Dengan adanya wacana pembangunan Gheotermal dinilai akan menyebabkan mereka akan kehilangan lahan pertanian atau juga bisa berdampak kepada aktivitas mereka sebagai petani ladang dan juga kerusakan lingkungan serta pencemaran sumber air di danau yang akan digunakan untuk pembangunan PLTP Gheotermal. HIMAPGTA dibentuk pada tahun 2019 sebagai suatu wadah untuk menampung aspirasi dan menyiapkan strategi jika pihak PT. Hitay Daya Energy datang kembali ke lokasi yang dijaga masyarakat, masyarakat yang tergabung dalam aliansi HIMAPAGTA telah menyiapakan strategi jika hal-hal yang tidak diinginkan terjadi, dan apa langkah kedepannya jika pihak perusahaan tetap masuk dan meneruskan pembangunan PLTP Gheotermal Gunung Talang.

2. Menyusun Strategi Pertahanan

Bentuk pertahanan yang dilakukan oleh masyarakat di Nagari Bukik Sileh serta Nagari Batu Bajanjang adalah dengan membentuk pos-pos pertahanan di lokasi eksplorasi pembangunan PLTP Gheotermal Gunung Talang, serta mengawasi setiap pendatang yang datang ke daerah mereka yang dicurigai sebagai pihak dari perusahaan. Masyarakat juga akan tetap mempertahankan tanah perladangan mereka yang berada di kaki Gunung Talang, masyarakat tidak akan menyerahkan tanah tersebut kepada PT.Hitay Daya Energy. Masyarakat akan memberikan perlawanan jika pembangunan PLTP Gheotermal Gunung Talang tetap dilanjutkan sebagai suatu upaya untuk mempertahankan tanah pertanian dan pekerjaan mereka.

3. Menjaga Lokasi Lahan Konflik

Masyarakat di Bukik Sileh serta Nagari Batu Bajanjang dalam upaya mempertahankan tanah mereka adalah dengan melakukan penjagaan secara bergiliran. Lokasi yang dijaga merupakan area perladangan masyarakat di kaki Gunung Talang tempat terjadinya konflik dengan pihak pemerintah 
serta pihak PT. Hitay Daya Energy. Penjagaan dilakukan untuk memantau pergerakan dari pihak perusahaan dan juga pihak-pihak luar lainnya yang dirasakan bisa merugikan masyarakat. Penjagaan lokasi lahan konflik tersebut telah dilaksanakan dari tahun 2018 sampai sekarang untuk mempertahankan tanah perladangan mereka.

4. Menghimpun Massa

Salah satu bentuk solidaritas bersama yang dilakukan oleh masyarakat di Bukik Sileh serta Nagari Batu Bajanjang adalah dengan mengumpulkan massa untuk melakukan aksi demonstrasi. Aksi demontrasi yang dilakukan oleh masyarakat di kedua nagari tersebut sebanyak dua kali, aksi pertama dilakukan pada tanggal 13 Septermber 2017 dengan menghadirkan massa sebanyak 1.500 orang. Sedangkan aksi kedua dilakukan pada tanggal 02 Oktober 2017 dengan menghadirkan massa sebanyak 8.500 orang. Aksi yang dilakukan oleh masyarakat salingka (selingkar) Gunung Talang sebagai bentuk penolakan terhadap pembangunan Pembangkit Listrik Tenaga Panas Bumi (PLTP) Geothermal Gunung Talang oleh PT. Hitay Daya Energy.

\section{Penyuluhan Pentingnya Pembangunan Bagi Masyarakat dan Pentingnya Menjaga dan Melestarikan} alam dan lingkungan

Pelaksanaan kegiatan pengabdian berbasis riset, sebagaimana hal dalam pengabdian berbasis riset lainnya berupa melakukan pengabdian yang didasari atas penelitian awal yang dilakukan sebagai dasar berpijak dalam melaksanakan pengabdian, maka pengabdian yang dilakukan berupa penyuluhan bagi masyarakat akan pentingnya pembangunan bagi masyarakat dan juga penyuluhan akan pentingnya menjaga lingkungan alam sebagai warisan untuk anak cucu dan generasi berikutnya. Tujuan dari penyuluhan ini yang membahas dua aspek yakninya pentingnya pembangunan dan juga pentingnya menjaga kelestarian alam, sehingga nantinya masyarakat dalam memikirkan, menimbang dan ikut memperhitungkan keuntungan dan kerugian dari pembangunan dan juga kelestarian alam. Masyarakat diharapkan dengan kegiatan pengabdian berupa penyuluhan mengenai pentingnya pembangunan disatu sisi dan pentingnya pula menjaga kelestarian alam disisi lainnya, sehingga masyarakat semakin cerdas dalam memutuskan permasalahan yang ada di tempat merka dan tidak gampang untuk dihasut oleh pihak-pihak tertentu.

Kegiatan penyuluhan pembangunan penting untuk dilakukan, mengingat sebagian besar wilayah Indonesia merupakan wilayah pedesaan. Pembangunan antara pedesaan dan perkotaan masih terasa kesenjangan. Kota dengan pembangunannya yang pesat sementara desa masih banyak dalam kategori tertinggal. Pembangunan yang dilaksanakan di pedesaan diharapkan perlahan demi lahan akan menjadi tumbuh dan berkembang seiring dengan geliat pembangunan. Pelaksanaan pengabdian masyarakat dengan program pembangunan pedesaan berbasis riset memberikan pemahaman dan penyadaran kepada 
masyarakat akan pembangunan inovasi tekhnologi modern sebagai dampak dari globalisasi yang terjadi. Mau tidak mau, suka dan tidak suka tehnologi masuk ke tengah-tengah masyarakat yang dibawa oleh arus globalisasi. Maka perlu sekali penyuluhan dan penyadaran kepada masyarakat akan arti dan urgensi pembangunan.

Penyuluhan pembangunan yang dilakukan diarahkan merubah masyarakat menjadi lebih baik. Penyuluhan mengedapankan kepada memberdayakan masyarakat sehingga masyarakat nagari mempunyai akses pada sumber-sumber ekonomi. Memberdayakan masyarakat perang melawan kemiskinan dan kesenjangan dalam dalam pembangunan menjadi agenda penting dalam kegiatan pengabdian masyarakat yang dilakukan. Kegiatan penyuluhan dan memberdayakan masyarakat ini sebagai upaya dalam memberdayakan masyarakat sehingga masyarakat menyadari akan hakikat pembangunan dalam kehidupan masyarakat.

Masalah lingkungan juga menjadi salah satu isu dalam kegiatan pengabdian masyarakat ini. Ada dua faktor utama menjadi yang berkaitan dengan kerusakan lingkungan. Pertama, meningkatnya jumlah penduduk yang memiliki ketergantungan mata pencaharian dengan lingkungan, sehingga terjadi kerusakan alam. Faktor kedua. rendahnya kesadaran masyarakat dalam menjaga dan melestarikan hutan. Kegiatan pengabdian masyarakat berbasis riset yang dilakukan ini juga diperkaya dengan diskusi-diskusi dengan masyarakat mengenai lingkungan sehingga penyuluhan dan pemberdayaan yang dilakukan membantu mencari akar masalah dan menyelesaikan masalah mereka oleh mereka yang dipandu oleh penulis dalam kegiatan pengabdian masyarakat berbasis riset.

\section{Pembahasan}

Pengabdian masyarakat berbasis riset ini dengan riset awal yang dilakukan berdasarkan solidaritas masyarakat dalam upaya menghadapi konflik dengan perusahaan yang akan mendirikan PLTP Geothermal selain dibedah dengan kajian pemberdayaan juga dianalisis dengan teori konflik. Analisis dengan teori konflik ini didasari pada riset awal yang dilakukan sebelum dilakukan pengabdian, berupa adanya konflik masyarakat dalam menentang pendirian PLTP Geothermal di desa mereka. Maka analisis dengan teori konflik dipandang sesuai dengan analisis riset awalnya dalam membedah dan menganalis kasus ini. Bagi Coser konflik merupakan proses yang bersifat instrumental dalam pembentukan, penyatuan dan pemiliharaan struktur sosial. Konflik dapat menempatkan dan menjaga garis batas antara dua atau lebih kelompok. Konflik dengan kelompok lain dapat memperkuat kembali identitas kelompok dan melindungi agar tidak lebur ke dalam dunia sosial sekelilingnya (Tualeka, 2017:37). Terjadinya konflik antara masyarakat Nagari Bukik Sileh serta Nagari Batu Bajanjang dengan PT. Hitay Daya Energy menjadikan masyarakat memperkuat struktur hubungan sosial diantara mereka. Hubungan sosial masyarakat yang sebelumnya tidak kuat menjadi bersatu untuk melakukan perlawanan kepada pihak 
lawan untuk menolak pembangunan PLTP Goethermal Gunung Talang. Masyarakat yang bekerja sebagai petani ladang sebelumnya hidup dengan aman, ketika adanya rencana pembangunan PLTP Geothermal Gunung Talang di area perladangan dan pemukiman masyarakat maka masyarakat melakukan perlawanan secara bersama. Masyarakat di Nagari Bukik Sileh dan Batu Bajanjang memperkuat kembali identitas mereka, bergerak melakukan perlawanan bersama untuk menjaga tanah perladangan serta wilayah pemukiman mereka dari usaha pembangunan PLTP yang dilakukan oleh PT. Hitay Daya Energy.

Menurut Coser konflik dibagi menjadi dua macam, yaitu: konflik realistis, berasal dari kekecewaan terhadap tuntutan-tuntutan khusus yang terjadi di dalam hubungan dan dari perkiraan kemungkinan keuntungan para partisipan, dan yang ditujukan pada obyek yang dianggap mengecewakan. Konflik non-realistis, konflik yang bukan berasal dari tujuan-tujuan saingan yang antagonis, tetapi dari kebutuhan untuk meredakan ketegangan, paling tidak dari salah satu pihak. Konflik yang terjadi antara masyarakat Nagari Bukik Sileh serta Nagari Batu Bajanjang dengan pihak pemerintah serta PT.Hitay Daya Energy merupakan bentuk dari konflik realistis, dikarenakan adanya perasaan kecewa dan marah masyarakat terhadap upaya pengambilan tanah dan pembangunan PLTP Geothermal di nagari mereka. Masyarakat menjadi takut kehilangan tanah mereka untuk berladang, terjadinya kerusakan lingkungan, pencemaran udara, kekeringan, perubahan suhu serta bencana alam yang ditimbulkan jika tetap dilakukan pembangunan PLTP di kaki Gunung Talang.

Dengan adanya konflik ini masyarakat menjadi bersatu untuk menolak pembangunan PLTP Geothermal Gunung Talang dengan cara meningkatkan solidaritas bersama. Solidaritas yang dahulunya tidak kuat menjadi sangat kuat karena adanya kepentingan untuk mempertahakan tanah, tempat tinggal serta mata pencaharian mereka. Sudah sangat banyak upaya masyarakat untuk melakukan gerakan bersama dalam menjaga garis batas kelompok mereka, dengan membentuk aliansi bersama untuk mengatur strategi jika terjadi hal-hal yang tidak diinginkan sudah dipersiapkan. Sehingga dengan adanya konflik ini membawa dampak positif dalam memperkuat struktur sosial dalam kehidupan masyarakat di Nagari Bukik Sileh dan Nagari Batu Bajanjang. Struktur sosial yang diperkuat itu adalah dengan munculnya rasa solidaritas bersama untuk menjaga dan mempertahankan kepentingan mereka atas tanah dan wilayah.

Adapun dalam pengabdian masyarakat yang dilakukan dianalisis dengan Partisipatori Action Research, dengan membawa masyarakat terlebih dahulu tahu dan memahami masalah yang ada dan sedang mereka alami kemudian dibimbing untuk mencari masalah. Masalah dan akar masalah mereka dibimbing untuk menemukannya sehingga mereka juga berpikir bagaimana solusi untuk meyelesaikan masalah yang dihadapi. Analis dilakukan dengan tiga kegiatan, pertama, menyususn proposisi beberapa dapak positif dan dampak negatif darisuatu pembangunan proyek. Kedua, Memprediksi dampak positif 
dan negatif dari pembangunan proyek serta ketiga, belajar membuat keputusan berdasarkan analisis dan kajian berupa dampak positif dan negatif dari proyek pembangunan, sehingga masyarakat belajar dan dapat mengambil keputusan berdasarkan pertimbangan rasional bukan hanya pertimbangan dadakan apalagi dalam pengaruh orang lain.

\section{Kesimpulan}

Masyarakat yang bekerja sebagai petani ladang sebelumnya hidup dengan aman, ketika adanya rencana pembangunan PLTP Geothermal Gunung Talang pada tahun 2017 di area perladangan dan pemukiman masyarakat maka masyarakat melakukan perlawanan secara bersama. Masyarakat di Nagari Bukik Sileh dan Batu Bajanjang memperkuat kembali identitas mereka, bergerak melakukan perlawanan bersama untuk menjaga tanah perladangan serta wilayah pemukiman mereka dari usaha pembangunan PLTP yang dilakukan oleh PT. Hitay Daya Energy. Masyarakat takut kehilangan tanah mereka untuk berladang, terjadinya kerusakan lingkungan, pencemaran udara, kekeringan, perubahan suhu serta bencana alam yang ditimbulkan jika tetap dilakukan pembangunan PLTP di kaki Gunung Talang.

Sudah sangat banyak upaya masyarakat untuk melakukan gerakan bersama dalam menjaga garis batas kelompok mereka, seperti membentuk Himapagta, menyusun strategi pertahanan, menjaga lokasi lahan konflik, menghimpun massa untuk melakukan demonstrasi, menyumbang dana untuk melakukan demonstrasi, meminta dana untuk demonstrasi dari rumah ke rumah, ibu-ibu melakukan blokade demonstrasi.

Kegiatan pengabdian masyarakat berbasis riset yang dilakukan, dengan melakukan riset awal terlebih dahulu untuk membelajarkan dan memberdayakan masyarakat dalam melihat dan memandang akan arti sebuah pembangunan dari dua sisi, dari aspek pembangunan dan aspek pelestarian lingkungan. Sehingga dengan adanya kegiatan pengabdian masyarakat ini, masyarakat dapat memandang pembangunan proyek dari dua sisi berupa sisi pembangunan dan sisi lingkungan. Masyarakat juga diharapkan dapat belajar untuk mencari akar masalah dan menyelesaikan masalah dengan belajar mengkaji dampak positif dan negatif dari pembangunan yang dilakukan. Tidak hanya ekstrim dengan dampak positif saja dan juga tidak ekstrim dalam menolak saja, tapi belajar melihat dari dua sisi yaitu sisi positif dan sisi negatif yang ditimbulkan dari pembangunan proyek seperti proyek PLTP Geothermal di kampung mereka. 


\section{Daftar Pustaka}

Afrizal. Metode Penelitian Kualitatif. Jakarta: Pt Raja Grafindo Persada, 2014.

- - Metode Penelitian Kualitatif: Sebuah Upaya Mendukung Penggunaan Penelitian Kualitatif Dalam Berbagai

Disiplin Ilmu. Pt Rajagrafindo Persada, 2014.

Dirgantara, Davindra. "Persepsi Masyarakat Tentang Rencana Pembangunan Pltp Gunung Talang-Bukit Kili Di Kabupaten Solok" 1 (2018): 11.

Elly M. Setiadi Dan Usman Kolip. Pengantar Sosiologi Pemahaman Fakta Dan Gejala Permasalahan Sosial: Teori, Aplikasi, Dan Pemecahannya. (Jakarta: Kencana Prenada Media Group, 2011.

Irving M. Zeitlin. Memahami Kembali Sosiologi. Yogyakarta: Ada University Press, 1998.

Moleong, Lexy J. “Metodologi Penelitian Kualitatif / Penulis, Prof. Dr. Lexy J. Moleong, M.A. | Opac Perpustakaan Nasional Ri.,” 2013. Https://Opac.Perpusnas.Go.Id/Detailopac.Aspx?Id=1133305.

Walhi. "Pembangunan Pltp Gunung Talang - Bukit Kili, Diwarnai Pemaksaan Negara Dan Kriminalisasi Rakyat," May 17, 2018. Https://Www.Walhi.Or.Id/Pembangunan-Pltp-Gunung-Talang-BukitKili-Diwarnai-Pemaksaan-Negara-Dan-Kriminalisasi-Rakyat.

Pratama, Andina, Sulistya Wardaya, And Ika Pasca Himawati. "Upaya Penyelesaian Konflik Pembangkit Listrik Tenaga Uap Di Teluk Sepang." Community : Pengawas Dinamika Sosial 7, No. 1 (July 12, 2021): 26-39. Https://Doi.Org/10.35308/Jcpds.V7il.3263.

Putra, Juli Ishaq, Bob Alfiandi, And Afrizal Afrizal. "Strategi Pemanfaatan Sumber Daya Dalam Gerakan Sosial Perlawanan Komunitas Salingka Gunung Talang Terhadap Penetapan Wilayah Kerja Geotermal Gunung Talang-Bukit Kili, Kabupaten Solok, Sumatra Barat." Jurnal Pendidikan Tambusai 5, No. 1 (June 23, 2021): 2109-17.

Rofiah, Khusniati. “Dinamika Relasi Muhammadiyah Dan Nu Dalam Perspektif Teori Konflik Fungsional Lewis A. Coser." Kalam 10, No. 2 (December 30, 2016): 469-90.

Https://Doi.Org/10.24042/Klm.V10i2.10.

"Sari Marta Yolanda.Pdf," N.D.

Sastra Hadi, Eril, And Eka Vidya Putra. "Resistensi Masyarakat Terhadap Rencana Pembangunan Pltp (Pembangkit Listrik Tenaga Panas Bumi) Di Gunung Talang Kabupaten Solok.” Jurnal Perspektif 2, No. 3 (August 3, 2019): 236. Https://Doi.Org/10.24036/Perspektif.V2i3.95.

Soerjono Soekanto. Kamus Sosiologi. Jakarta: Pt Rajagrafindo Persada, 1993.

Suardi Wekke, Ismail. "Metode Penelitian Sosial,” 2019.

Suppa, Rinto. "Perubahan Sosial Pasca Konflik (Studi Di Kecamatan Lambu Kabupaten Bima).” Masters, Pascasarjana, 2014. Http://Eprints.Unm.Ac.Id/4651/.

Tualeka, M Wahid Nur. “Teori Konflik Sosiologi Klasik Dan Modern,” 2017, 17. 
